\begin{tabular}{|c|c|c|c|}
\hline Eiszeitalter u. Gegenwart & $\mathbf{4 7}$ & $\begin{array}{c}78-88 \\
8 \text { Abbildungen }\end{array}$ & Hannover 1997 \\
\hline
\end{tabular}

\title{
Patterns of Late Glacial vegetation in The Netherlands
}

\author{
Wim Z. HoeK*)
}

Weichselian Late Glacial, vegetational development, climate, The Netherlands

\begin{abstract}
The Weichselian Late Glacial (ca. 13,000 - 10,000 years BP) marks the transition from the cold Weichsel Late Pleniglacial to the warmer Holocene. During this period the climate rapidly changed as did the vegetation and the abiotic landscape. The vegetational development of the Weichselian Late Glacial in The Netherlands is determined firstly by the large-scale changes in climate and in the second place by local variations in lithology, geomorphology and hydrology. Pollen diagrams from different areas, embracing the same time-stratigraphical interval, often show clear variations in vegetation history, which can not be explained on climatological grounds alone.

In The Netherlands over 400 palynological sections, covering a part or the whole of the Weichselian Late Glacial, have been investigated by several institutes. For the compilation of the data from over 250 pollen diagrams, use was made of the European Pollen Database structure. Dated shifts in the arboreal pollen content constitute the basis of a regional zonation scheme. With the help of this, iso-pollen maps of main taxa were constructed for different timewindows within the Weichselian Late Glacial. The dense network of palynological observation sites in The Netherlands permitted the drafting of high-resolution iso-pollen maps of the period considered. A clear relationship can be recognized between the iso-pollen patterns and the landscape type. Thus, it should be possible to distinguish more clearly between climate and other abiotic agencies of the environment which affected vegetational development.
\end{abstract}

\section{[Spätglaziale Vegetationsverteilung in den Niederlanden]}

Kurzfassung: Das Weichsel-Spätglazial (ca. 13.000-10.000 Jahre vor heute) markiert den Übergang vom kalten späten Weichsel-Pleniglazial zum wärmeren Holozän. Während dieser Periode änderten sich Klima, Vegetation und die abiotische Landschaft sehr rasch. Die Vegetationsentwicklung im Weichsel-Spätglazial der Niederlande wird in erster Linie durch langfristige Klimaänderungen und an zweiter Stelle durch Veränderungen der Lithologie, Geomorphologie und Hydrologie gesteuert. Pollendiagramme aus verschiedenen Regionen, die das gleiche stratigraphische Intervall umfassen, zeigen oft deutliche Variationen in der Vegetationsgeschichte, die nicht allein mit klimatischen Veränderungen erklärt werden können.

Über 400 Profile, die Teile oder das gesamte WeichselSpätglazial umfassen, wurden in den Niederlanden von

*) Anschrift des Verfassers: Dr. W. Z. Hoek, The Netherlands Centre for Geoecological Research (ICG), Faculty of Earth Sciences, Vrije Universiteit Amsterdam, De Boelelaan 1085, 1081 HV Amsterdam, The Netherlands. verschiedenen Instituten untersucht. Zur Kompilation von mehr als 250 Pollendiagrammen wurde die European Pollen Databasestruktur genutzt. Datierte Veränderungen im arborealen Pollenbestand bilden die Grundlage des regionalen Zonierungsschemas. Mit Hilfe dieser Daten wurden Iso-Pollen-Karten der wichtigsten Taxa für verschiedene Zeitfenster des Weichsel-Spätglazials konstruiert. Die hohe Beobachtungsdichte palynologischer Daten in den Niederlanden erlaubte die Konstruktion hoch auflösender IsoPollen-Karten für den betrachteten Zeitraum. Es gibt eine klare Beziehung zwischen den beobachteten Iso-PollenMustern und dem Landschaftstyp. Es sollte nun möglich sein, klarer zwischen klimatischen und abiotischen Faktoren $z u$ unterscheiden, die die Vegetationsentwicklung steuern.

\section{Introdution}

The Weichselian Late Glacial marks the transition between the cold Weichselian Late Pleniglacial and the warmer Holocene. The climate change during this transition caused the vegetation and the abiotic component of the landscape to change rapidly. A great number of palynological data considering the Late Glacial have been collected in NW-Europe and especially The Netherlands during the last decades. Therefore, the general vegetation development for this period is well known.

At the end of the Weichselian Late Pleniglacial there was in The Netherlands a sparse vegetation cover comprising Gramineae, Cyperaceae and Betula nana, many places were altogether bare. From around 13,000 years BP herbaceous plant communities and dwarf bushes developed due to temperature rise. During the Alleriød interstadial rather open $B e_{-}$ tula and later on Pinus woods occurred. The colder Late Dryas stadial interrupted around 10,950 BP the development to a more dense vegetation cover. The Pinus and Betula woods diminished in size and herbaceous plant communities comprising Empetrum nigrum, developed. At the start of the Holocene (10,150 years BP) Betula and later on Pinus woods expanded again and became more dense as a result of temperature rise. Thermophilous trees as Corylus, Quercus, Tilia, Ulmus and Alnus appeared later in the Holocene and are supposed to have been absent during the Late Glacial in The Netherlands. This general vegetation development can be recognized in most of the pollendiagrams from The Netherlands. 


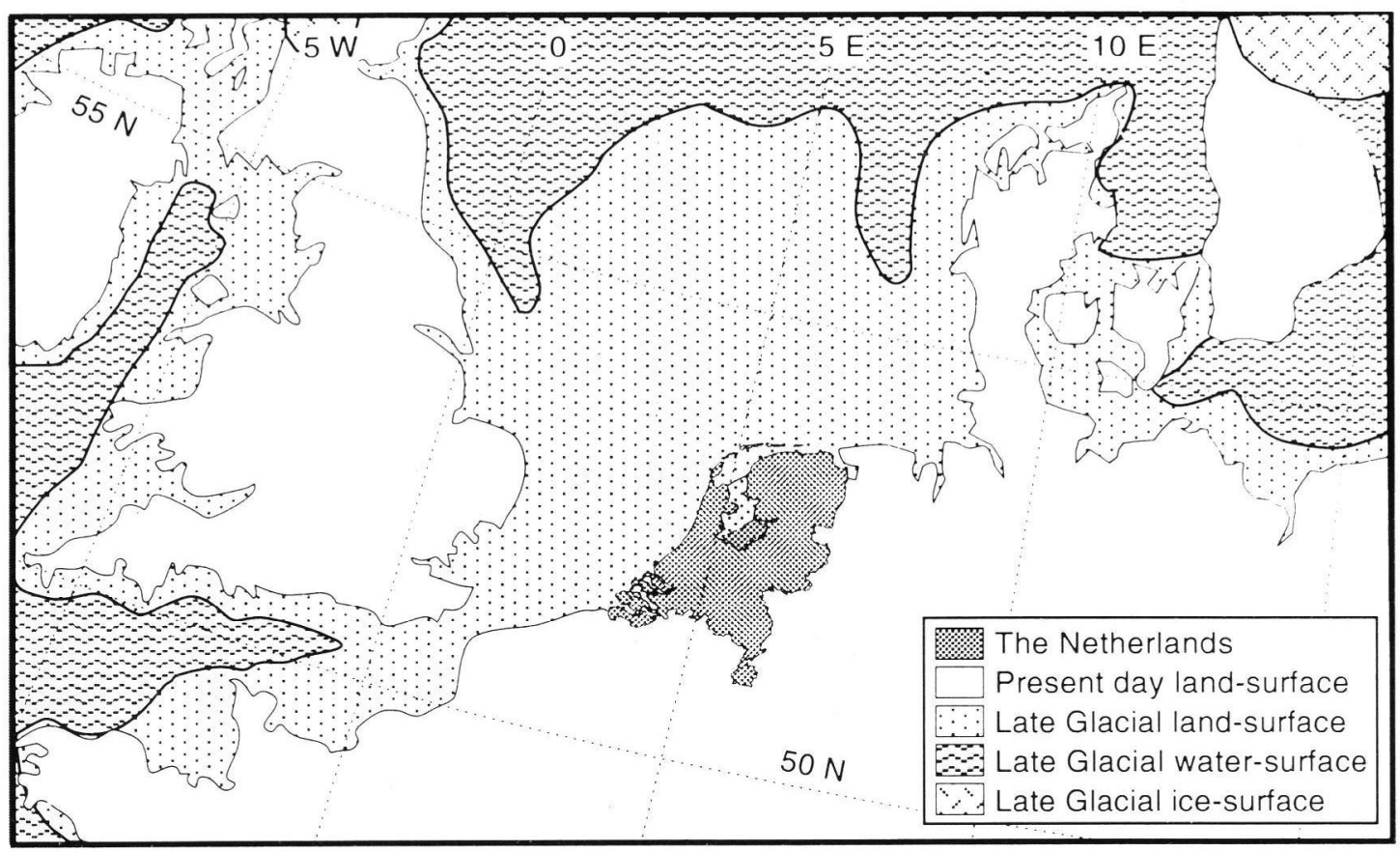

Iigure 1. The continental position of the Netherlands during the Weichselian Late Glacial (modified after JeLgersma, 1979 and LANG, 1994).

Abb. 1: Die kontinentale Lage der Niederlande während des Weichsel Spätglazials (modifiziert nach JELgERsMA 1979 und LANG 1994)

However, pollen diagrams from different areas in The Netherlands show clear variations in pollen composition during the Late Glacial.

\section{Palaeogeographical approach}

For The Netherlands it is to be expected that there were only small spatial differences in climate during the Weichselian Late Glacial due to the small area and relatively large distance to the former coastline. As sealevel was between 90 and 65 meters below the present date level (Jelgersma, 1979), the coastline was more than 200 kilometers away and any climate gradient induced by the sea can be neglected for The Netherlands during the time under investigation. Figure 1 shows the relative continental position of The Netherlands during the Weichselian Late Glacial (modified after Jelgersma, 1979 and Lang, 1994).

In the classical approach, single locations are the main basis for palaeoclimate reconstructions. It is obvious that climate parameters derived from single pollen diagrams will represent certain local influences. The main reason for this is the fact that not only the large scale changes in climate determined the vegetation development in for instance the Weichselian Late Glacial. Also more local variations in lithology, geomorphology and geo-hydrological conditions have influenced the vegetation development and patterns. Palaeoclimate reconstructions based on single pollen diagrams will therefore give a wrong picture of the regional climate.

With a palaeogeographical approach the vegetation patterns and changes in the patterns can be compared with geological/geomorphological maps. As soon as the relations between the palaeovegetation and the abiotic components of the landscape are known, the relations between vegetation and climate will be more clear. This approach requires a dense network of palynological sections in an area with a well known geology and geomorphology.

\section{The Late Glacial abiotic landscape of The Netherlands}

The Late Glacial landscape is a landscape with changing geomorphology and vegetation. During the Weichselian Late Glacial geomorphological processes were active, but the abiotic changes where not as large as during the preceding Pleniglacial. Morphological features related to permafrost that had existed at the end of the Pleniglacial disappeared due to the changes in climate towards the Holocene. Permafrost disappeared, although deep seasonal frost may have occurred during the Late Glacial (VANDENBERGHE, 1992). The vegetation development initiated soil formation and stabilized the substratum. The 


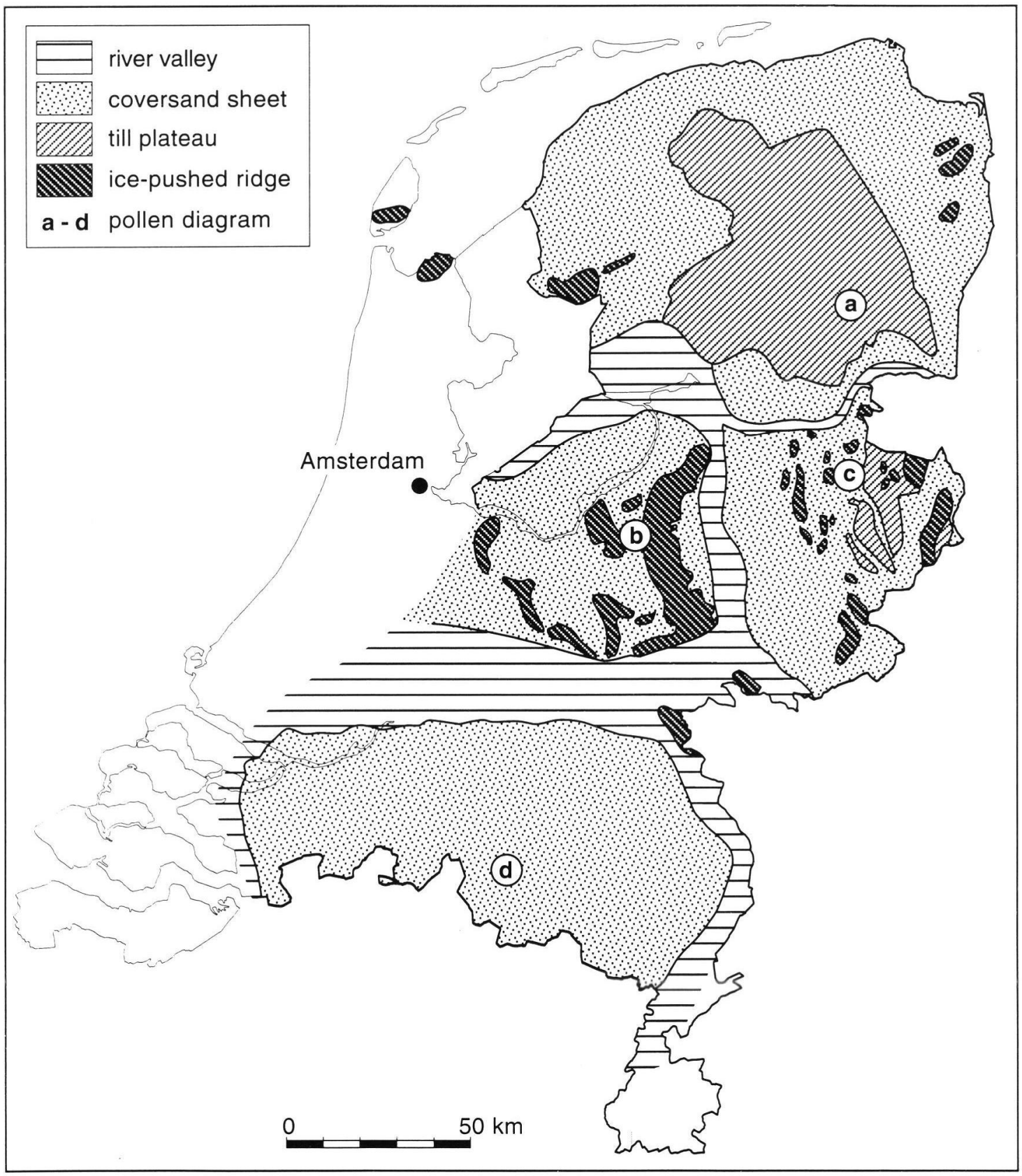

Figure 2. Reconstruction of the landscape types in The Netherlands during the Weichselian Late Glacial (modified after Zagwijn, 1986).

Abb. 2: Rekonstruktion der Landschaftstypen in den Niederlanden während des Weichsel Spätglazials (modifiziert nach ZAGwIJN 1986)

main landscape types that existed during the Late Glacial in The Netherlands are formed by glacial, fluvial and aeolian processes. For The Netherlands in general five larger landscape regions existed during the Late Glacial.

1 The till region in the northern Netherlands was formed as a result of the Saalian glaciation. Glacial tills form the substratum in a gently undulating landscape. In this region hundreds of Pleniglacial pingo remnants occur (De Gans, 1981). From these pingo remnants, formed after melting of the pingos at the end of the Pleniglacial, many pollendiagrams have been obtained.

2 The ice-pushed region in the central Netherlands 


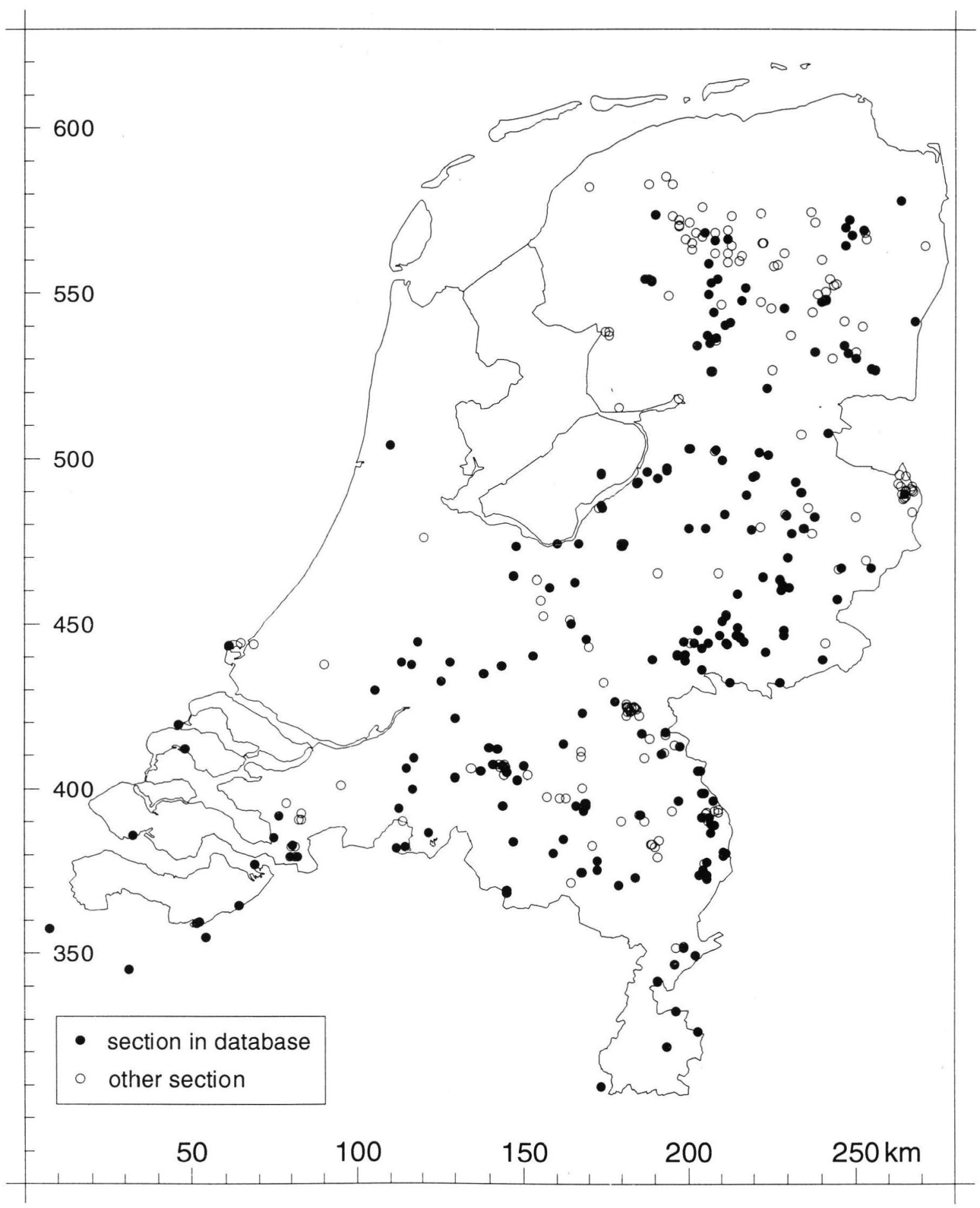

Figure 3. Late Glacial palynological sections in The Netherlands.

Abb. 3: Spätglaziale palynologische Profile in den Niederlanden.

includes the end moraines of the Saalian ice-sheets. The hills rise up to a hundred meters above the surrounding river deposits and are built of older river deposits. Between the ice-pushed ridges deposition of coversands took place during the Weichselian Pleniglacial and Late Glacial (MAARLE- 


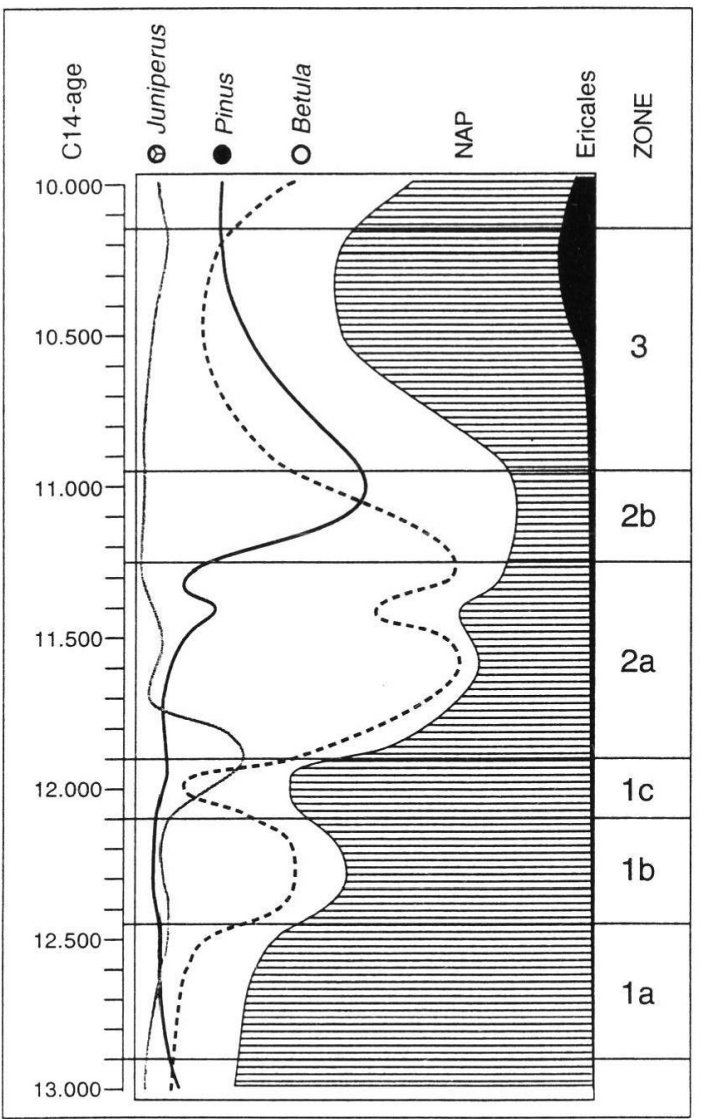

Figure 4: Regional Late Glacial pollen diagram of the main taxa for The Netherlands.

Abb. 4: Regionale spätglaziale Pollendiagramme der wichtigsten Taxa für die Niederlande.

VELD \& VAN DER SCHANS, 1961). As the ice-pushed ridges consist mainly of well-drained gravels and sands, only a few wet basins occur where organic deposits could be preserved.

3 The river region in the central Netherlands is mainly formed by the rivers Rhine and Meuse. As the rivers changed their patterns and morphology between braiding and meandering due to climate change, the abandoned river channels form the basins where organic deposits could be preserved. Under dry conditions during the second phase of the Late Dryas stadial, sand was blown out of the braided river beds, forming riverdunes in the surrounding vegetation cover (BoHncke et al. 1993). The river landscape during the Late Glacial has been described by Kasse et al. (1995) and Berendsen et al. (1995).

4 The coversand region in the eastern Netherlands is characterized by thick layers of coversand formed during the Weichselian Pleniglacial (SCHWAN, 1988). In this region Saalian ice-pushed ridges occur also.
During the Late Dryas stadial a layer of coversand was deposited over soils and peats, indicating the landscape was more open than in the preceding Allerød interstadial. The organic deposits in this area consist of peats and shallow lacustrine deposits formed in the depressions between coversand ridges.

5 The coversand region in the southern Netherlands is characterized by a gently undulating topography. The coversands are mainly deposited during the Weichselian Pleniglacial (Schwan, 1988). In the western part, Early Pleistocene clayey deposits occur at shallow depth. Like in the eastern coversand region, organic deposits in this area consist of peats and shallow lacustrine deposits formed in the depressions between coversand ridges. Some smaller pingo remnants occur (KASsE \& BOHNCKE, 1992).

In figure $2 \mathrm{a}$ reconstruction of the landscape in The Netherlands during the Weichselian Late Glacial is given (modified after ZAGwIJN, 1986).

\section{Available palynological data}

In The Netherlands over 400 palynological sections have been investigated by several institutes during the last decades, covering part or whole of the Weichselian Late Glacial. Most of the investigated sections are unpublished and the original data are stored as counting sheets in archives of the Geologi(al Survey, Soil Survey and different universities. As a first step in this study, the pollen countings were gathered and inserted into a computer. By now 250 of these sections are available in digital format. The data are stored in a relational database, using the European Pollen Database structure. The spatial density of available pollen data decreases in westery direction, directly related to the depth of the Late Glacial deposits below the present day surface. In the most western part of The Netherlands the Late Glacial deposits are covered with up to 15 meters of Holocene fluvial sediments, marine sediments and peat. Therefore, Late Glacial deposits are difficult to collect. Nevertheless, the spatial resolution is high, as can be seen in figure 3. The locations of the pollen diagrams which are stored in the database are presented as black dots, while the other locations are presented as open circles. With this dense pattern of palynological investigated locations a reconstruction of the vegetation patterns in different time windows during the Welchsellan Late Glacial can be made.

\section{Preparation of the palynological data}

For the construction of the pollen diagrams from the pollen countings a uniformous pollen sum was used to calculate percentages, so the diagrams can be compared. In the pollen sum only non-thermo- 
A) Mekelermeer

B) Uddelermeer

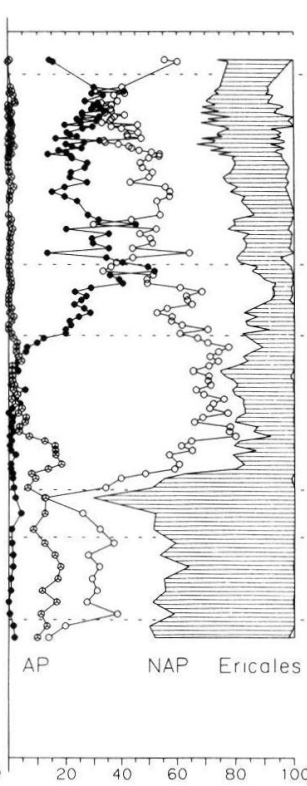

C) Daarle

D) Middelbeers
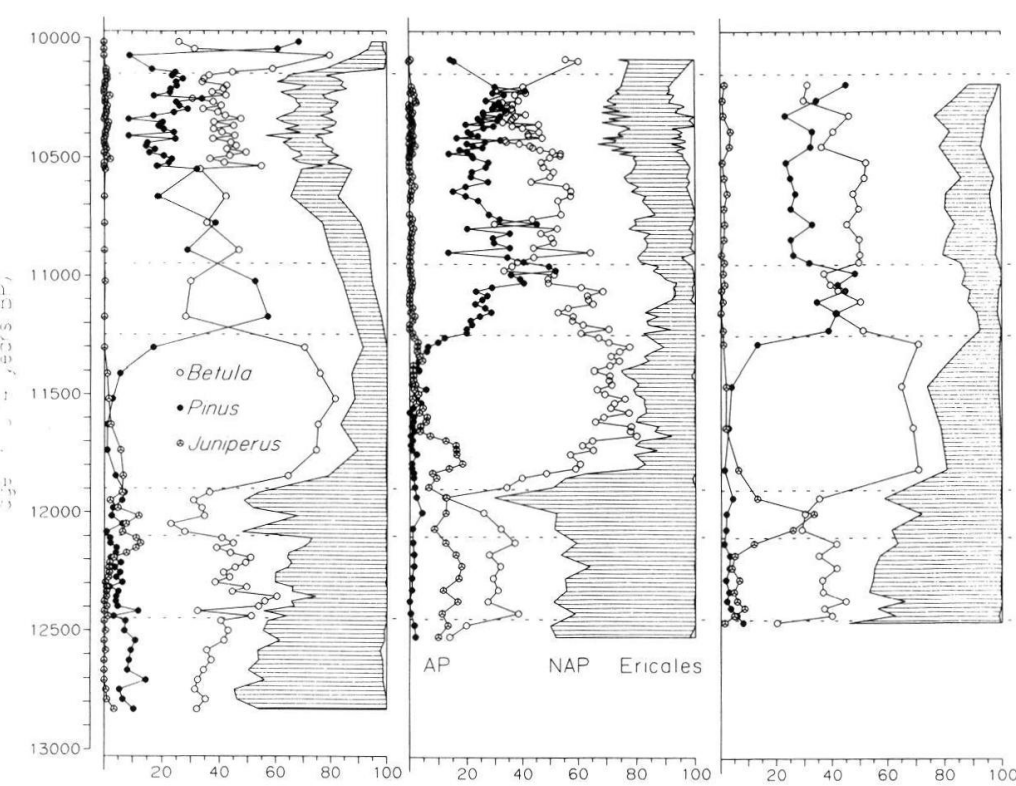

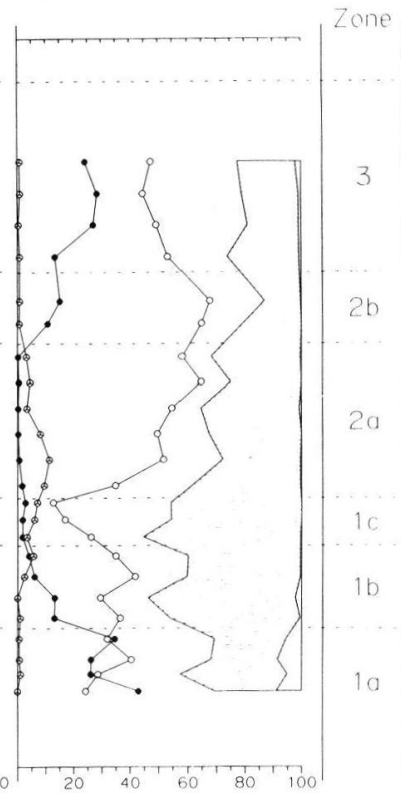

Figure 5: Pollen diagrams with selected taxa from 4 small basins in different regions.

a Mekelermeer (BoHncke et al., 1988); b Uddelermeer (BoHncKe et al., 1988); c Daarle (BIJlsma \& DE LANGe, 1983); d Middelbeers (KoElbloed, 1969).

Abb. 5: Pollendiagramme ausgewählter Taxa aus vier kleinen Becken in verschiedenen Regionen.

a Mekelermeer (BOHNcke et al., 1988); b Uddelermeer (BOHNCKE et al., 1988); c Daarle (BIJLSMA \& DE LANGE, 1983); d Middelbeers (KoelbLoed, 1969).

philous trees, shrubs and dry herbs are included, regional taxa sensus Janssen (1973). The local pollen taxa, aquatics and riparian herbs including Cyperaceae, as well as thermophilous tree pollen and spores were excluded from the pollen sum. The major shifts in the main pollen taxa, radiocarbon dated in several pollen diagrams distributed over The Netherlands, are used to construct a regional zonation (НоEK, in prep.). In figure 4 the zonation is present-ed as a generalized Late Glacial pollen diagram for The Netherlands on an uncalibrated radiocarbon timescale. Based on the zonation, a zone code has been assigned to the analyzed levels from the pollen diagrams in the database. If any uncertainties appeared, for instance in the case of a pollen sum less than 100 , indications for reworking or contamination, no zone code was assigned to that level. In figure 5a-d four pollendiagrams with selected taxa are presented. The pollendiagrams are derived from small (former) lakes, pingo remnants from the northern Netherlands till region (a), the central Netherlands ice - pushed region (b) and the eastern (c) and southern $(d)$ coversand region. In these diagrams the differences between the percentages of Juniperus, Pinus and Ericales can be seen. The higher percentages of Pinus and Ericales at the, minerogenic, lower part of some of the diagrams are caused by reworking from older deposits.
Juniperus in zone Ic reaches the highest values up to $30 \%$ in the diagram from the eastern coversand region (c) and 15\% in that from the central Netherlands (b). During the following zone $2 \mathrm{a}$, the highest values for Juniperus, up to $30 \%$ are recorded in the diagrams from the central Netherlands and 10\% in the southern coversand region (d).

During zone $2 \mathrm{~b}$ Pinus has the highest value round $50 \%$ in the diagrams from the till region, the central Netherlands and the eastern coversand region. The values for Pinus in the diagram from the southern coversand region remain below $20 \%$.

The percentages of Ericales, including Empetrum nigrum, during zone 3 are the highest in the diagram from the northern Netherlands till region with values up to $25 \%$. The diagrams from the central Netherlands and the eastern coversand region show values up to $10 \%$ and $7 \%$ respectively. For each pollen diagram in the database the mean and maximum values of the main taxa have been computed for the distinguished zones.

\section{Construction of the iso-pollen maps}

For three zones within the Late Glacial iso-pollen maps were constructed showing the highest percentages of the distinctive taxa in that zone. Zone Ic and the base of zone $2 \mathrm{a}$ are characterized by high values of Juniperus communis (Juniper), a species spread 


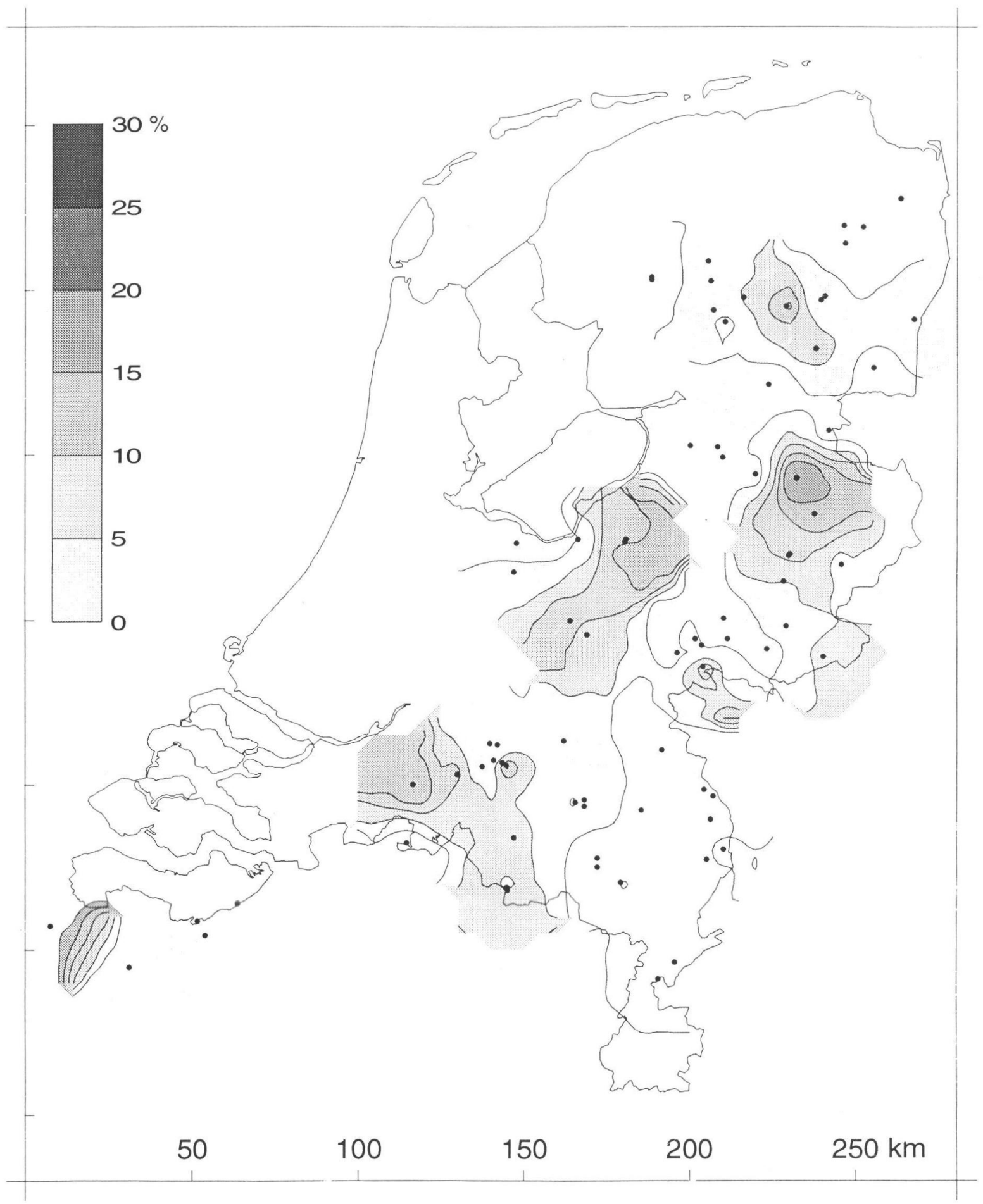

Figure 6: Iso-pollen map for the maximum values of Juniperus between 12,100-11,500 BP (zone Ic/2al). Abb. 6: Iso-Pollen-Karte für Maximalwerte von Juniperus zwischen 12.100 und $11.500 \mathrm{BP}$ (Zone Ic/2al).

by birds and favoured by the presence of a bare sandy substratum. Zone $2 \mathrm{~b}$ is characterized by high values of Pinus sylvestris (Scots pine) which migrat- ed around 11,250 BP from the south-east, presumably distributed along the river Rhine course. Zone 3 is characterized by high values of Ericales, especial- 


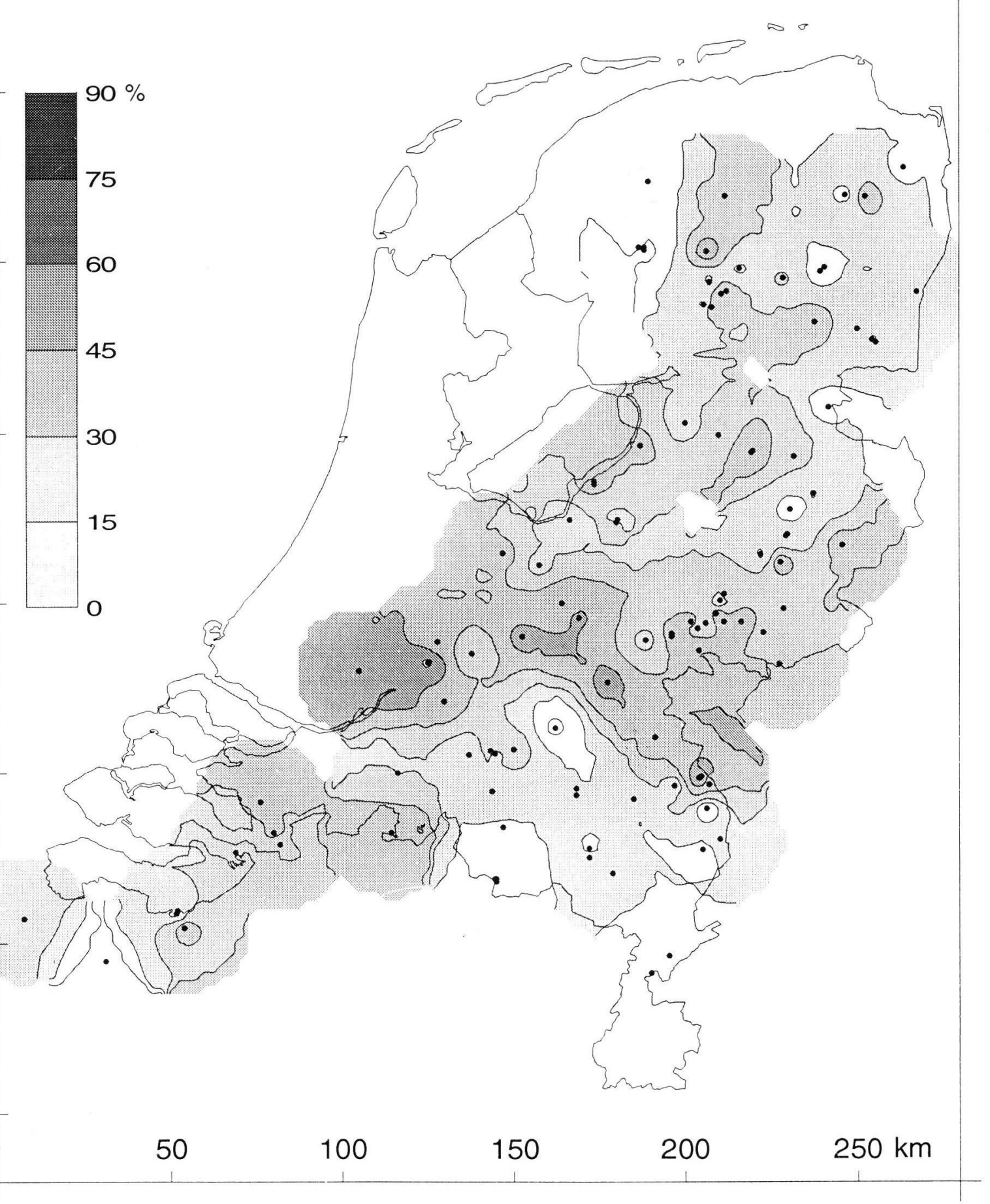

Figure 7: Iso-pollen map for the maximum values of Pinus between 11,250-10,950 BP (zone 2b). Abb. 7: Iso-Pollen-Karte für Maximalwerte von Pinus zwischen 11.250 und 10.950 BP (zone 2b).

ly in the second part of this zone. Empetrum nigrum (Crowberrry), the main constituent of the Ericales during this zone is spread by birds. It can be dem- onstrated that the percentages of the characteristic pollen taxa of each zone vary with the landscape type. HuNTLEY \& Birks (1983) presented iso-pollen maps 


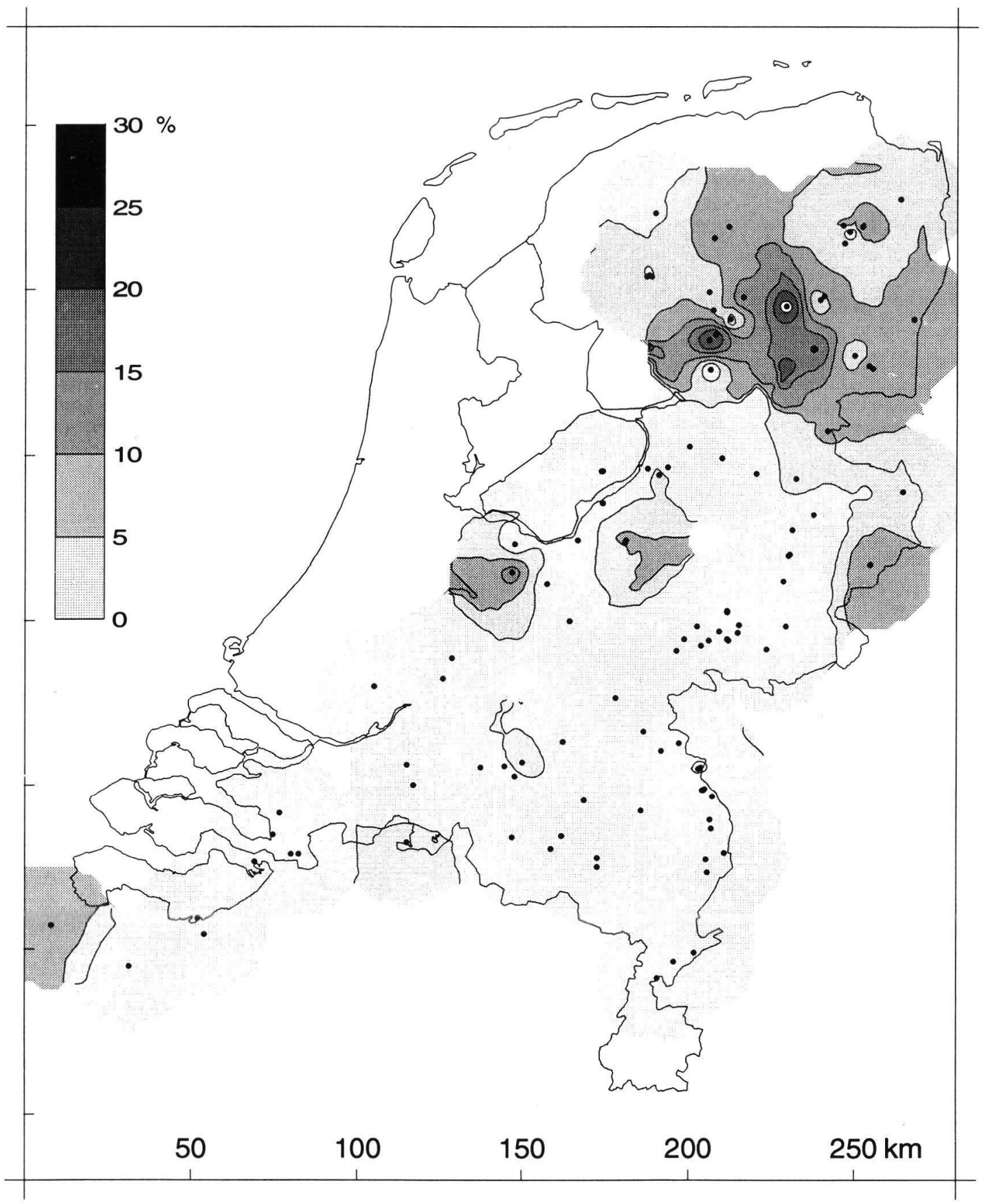

Figure 8: Iso-pollen map for the maximum values of Ericales between 10,950-10,150 BP (zone 3). Abb. 8: Iso-Pollen-Karte für Maximalwerte von Ericales zwischen 10.950 und $10.150 \mathrm{BP}$ (zone 3).

which show large scale patterns in pollen percentage over Europe. The spatial resolution of these maps of Europe is unavoidably low and these maps can not be used for regional analyses. For the construction of the iso-pollen maps in this study, the locations with their maximum value for 
the specific taxa within their distinct zone were retrieved from the database. Iso-pollen maps were constructed using a squared inverse distance interpolation with a search radius of 20 kilometers. The search radius is in accordance with the possible source area of the regional pollen record. In areas where no data were available within the search radius the outcome has automatically been blanked. Thus no extrapolations towards areas without data have been made. The data points used in the interpolation are displayed as black dots.

For zone Ic and the base of zone $2 \mathrm{a}$, the time-window from 12,100 - 11,500 $\mathrm{BP}$, the highest percentages of Juniperus are plotted in figure 6. The presence of Juniperus pollen during these zones is recorded in 82 pollen diagrams in the database.

For zone $2 b$, the time-window from 11,250 - 10,950 BP, the highest percentages of Pinus are plotted in figure 7. The presence of Pinus pollen during pollen zone $2 \mathrm{~b}$ is recorded in 113 pollen diagrams in the database. For zone 3, the time-window from 10,950 - 10,150 $\mathrm{BP}$, the highest percentages of Ericaes (mainly Empetrum nigrum) are plotted in figure 8. The presence of Ericales pollen during pollen zone 3 is recorded in 114 pollen diagrams in the database.

\section{Relationship between the iso-pollen patterns and the abiotic landscape}

The highest percentages Juniperus during zone Ic and $2 \mathrm{a}$ with values up to 30 percent are related to the ice-pushed ridges in the central and eastern Netherlands and the southern Netherlands coversand region. These areas consist of the more sandy welldrained sediments. The growth of Juniperus communis is favoured by a bare sandy substratum and is therefore likely to have been growing in the coversand areas. Lower percentages are recorded in the river valleys and the northern Netherlands till region, areas with higher groundwater levels and a less sandy substratum. The highest values of Pinus during zone $2 \mathrm{~b}$ are recorded in the central Netherlands river region. The lowest values are recorded in the eastern part of the southern Netherlands coversand region. There seems to be no south-north gradient in the percentage of Pinus as suggested by several authors. As Pimus sylvestris is at present growing on drier locations, it is supposed that Pinus was not inhabiting the river valleys but grew on the higher parts of the terraces along the river valleys. The high percentages of Pinus in the central Netherlands river region may also be a result of a more open herbaceous vegetation type, suggesting Pinus is overrepresented due to long distance transport.

The iso-pollen map for the maximum values of Ericales during zone 3 (figure 8), shows the high values, over $20 \%$, linked to the poorly drainage and leached soils in tills situated in the northern Netherlands. In the ice-pushed region of the central Netherlands and western part of the southern Netherlands coversand area percentages above $10 \%$ occur, presumably related to the occurrence of a clayey substratum at shallow depth. Pollen diagrams from the coversand area and the nutrient rich river area show values below 5\% for Empetrum during zone 3. The high occurrence of Empetrum nigrum is often used as an indicator for oceanity, based on higher precipitation rates. At present, a higher occurrence of $\mathrm{Em}$ petrum indicates a low nutrient availability or acid soils, a situation occurring already in the till region during the time under investigation. Empetrum is able to grow in areas with an active aeolian sedimentation, a situation that occurred during the second phase of the Younger Dryas (BoHncke et al., 1993).

\section{Conclusions}

Not only climatic changes (temperature and precipitation) influenced the vegetation development. Also more local variations in lithology, geomorphology and geo-hydrological conditions influenced the vegetation and especially the vegetation patterns. As the vegetation in The Netherlands, and other areas, will not have been uniformous during the Late Glacial one has to be careful with deriving the climate signal from single pollen diagrams.

As The Netherlands occupied a relative continental position during the Weichselian Late Glacial, it is not feasible that differences in the pattern of Ericales during the Late Dryas stadial are caused by a climatic gradient over The Netherlands. There will, however have occurred a climatic event causing the great expansion of Empetrum nigrum in the areas favourable for this species.

\section{Acknowledgements}

This study forms part of the project: Palaeogeography of Late Glacial vegetations: analysis in time and space.

Aim of this project is to reconstruct the Late Glacial vegetation in the northwest-european lowland in relation to climate and the abiotic components of the landscape.

The project is sponsored by The Netherlands Organization for Scientific Research (N.W.O.- G.O.A.) and is incorporated in the research program of The Netherlands Centre for Geo-ecological Research (ICG). Supervisor of the project is Prof. Dr. W. H. Zagwijn, who is acknowledged for his valuable comments on the text.

The palynological data used in this study were kindly provided by the following institutes; The Netherlands Geological Survey (RGD), DLO Staring Centre, Wageningen, Laboratory for Palaeo-ecology and Landscape-evolution (University of Gent, Belgium), 
Hugo de Vries Laboratory (University of Amsterdam), Laboratory for Palynology and Palaeobotany (University of Utrecht), Institute for Prehistory (University of Leiden) and the Faculty of Earth Science (Vrije Universiteit Amsterdam).

\section{References}

Berendien H.J.A., Hoek, W.Z. \& Schorn, E.A. (1995): Late Weichselian and Holocene river channel changes of the rivers Rhine and Meuse in the Netherlands (Land van Maas en Waal). Paliäoklimaforschung Palaeoclimate Research, 14, 151-171.

Bitlsma, S. \& DE LANGE, G.W. (1983). Geology, palynology and age of a pingo remnant near Daarle, province of Overijssel, The Netherlands. Geologie en Mijnbouw, 62, 563-568.

Bohncke, S.J.P., Wljmstra, L., van der WOUde, J. \& SOHL, H. (1988). The Late-Glacial infill of three lake successions in The Netherlands: Regional vegetational history in relation to NW European vegetational developments. Boreas, 17, 385-402.

Bohncke, S.J.P., Vandenderghe, J.F. \& Hujzer, A.S. (1993): Periglacial Paleoenvironments during the Late Glacial in the Maas Valley, The Netherlands. Geologie en Mijnbouw, 72, 193-210.

DE GANS, W. (1991): Location, age and origin of pingo remnants in the Drentsche Aa valley area (The Netherlands). Geologie en Mijnbouw, 61, 147-158.

Huntley, B. \& Birks, H.J.B. (1983): An atlas of past and present pollen maps for Europe: 0-13,000 years ago. Cambridge University Press, $667 \mathrm{pp}$.

JANSsEN, C.R. (1973): Local and regional pollen deposition. In: Birks, H.J.B. and West, R.G. (eds), Quaternary Plant Ecology, pp. 3142, Blackwell Scientific Publications, Oxford.
Jelgersma, S. (1979): Sea-level changes in the North Sea basin. In: Oele, E., Schüttenhelm, R.T.E. and Wiggers, A.J. (eds), The Quaternary History of the North Sea, pp. 233-248. Acta Universitas Uppsala, 2, Uppsala. 249.

Kasse, C. \& BOHNCKE, S.J.P. (1992): Weichselian Upper Pleniglacial Aeolian and Ice-cored Morphology in the Southern Netherlands (Noord-Brabant, Grootc Peel). Permafrost and Periglacial Processes, 3, 327-342

Kasse C., VANDENBerghe, J.F. \& BOHNCKE, S.J.P. (1995): Climate change and fluvial dynamics of the Maas during the late Weichselian and early Holocene. Paläoklimaforschung Palaeoclimate Research, 14, 123-150.

KoelBLoed, K.K. (1969): Pollen diagram Middelbeers meerven. Intern rapport van de Stichting voor Bodemkartering, afdeling palaeobotanie, $2 \mathrm{pp}$

LANG, G.H. (1994): Quartäre Vegetationsgeschichte Europas. Gustav Fischer Verlag, Jena. 462 pp.

MaArleveld, G.C. \& Van DeR Schans, R.P.H.P. (1961): De dekzandmorfologie van de Gelderse Vallei. Tijdschrift van het Koninklijk Nederlands Aardrijkskundig Genootschap, 78, 22-34.

SCHWAN, J. (1988). The structure and genesis of Weichselian to Early Holocene aeolian sand sheets in Western Europe. Sedimentary Geology, 55, 197-232.

Vandenberghe, J.F. (1992): Periglacial Phenomena and Pleistocene Environmental Conditions in the Netherlands - An Overview. Permafrost and Periglacial Processes, 3, 363-374.

ZAGWIJN, W.H. (1986): Nederland in het Holoceen. Rijks Geologische Dienst, Haarlem, The Netherlands, 46 pp.

Manuskript eingegangen am 17. 05. 1996 